\title{
Whose Justice? Which Democracy? \\ Justice, Reconciliation and Democracy in Post-Genocide Rwanda - Challenges to Public Theology
}

\author{
Dr. Christine Schliesser \\ Institute for Social Ethics, Zurich University, Switzerland/ \\ Studies in Historical Trauma and Transformation, Stellenbosch University, South Africa \\ christine.schliesser@sozethik.uzh.ch
}


How can a public theology advance the task of democracy in order to bring forth justice for all? This article focuses on post-genocide Rwanda as a current example of a country's quest for justice, reconciliation and democratization after severe violent conflict. The first part traces the historical background of the Rwandan genocide with specific attention on the lack of just and democratic structures in pre-genocide Rwanda and the roles of the Christian churches therein. The second part explores the Christian churches' involvement in the country's current reconciliation process. Here, the Presbyterian Church of Rwanda (EPR) serves as a case study. The third part critically assesses the churches' contribution to reconciliation with regards to how it serves to enhance - or hinder - the implementation of just and democratic structures.

Keywords: Rwanda; public theology; democracy; justice; reconciliation; genocide

\section{Introduction}

How can a public theology advance the task of democracy in order to bring forth justice for all? The challenge entailed in this question multiplies when it is set in the context of societies-intransition, in the aftermath of individual and structural injustice and gross human rights violations. There are many stories to be told in this regard, South Africa, the Balkans, Columbia, not to mention Syria and Iraq. The focus for this article will be on the story of Rwanda and the Rwandan genocide, however, when up to 1.000 .000 people lost their lives between April and July 1994. I will look at post-genocide Rwanda as a current example of a country’s quest for justice, reconciliation and democratization in the wake of violent conflict. Coming from the disciplinary perspective of a public theology that holds to the relevance of both theology and the churches for public life, I will explore the Rwandan churches' contribution to these processes. My analysis proceeds in three steps.

In the first part, I will briefly trace the historical background of the Rwandan genocide with specific attention being paid to the role of the Christian churches and the lack of just and democratic structures in society. This initial step will be followed, secondly, by an exploration of the Christian churches' involvement in the country's current reconciliation process. Here, the Presbyterian Church of Rwanda (EPR) serves as a case study. The third part critically assesses the churches' contribution to reconciliation with regards to how it serves to enhance or hinder - the implementation of just and democratic structures. 


\section{The Rwandan Genocide: Complicity of the Churches?}

With about half the size of Switzerland Rwanda is one of the smallest African countries. It leapt into general consciousness when in 1994 a genocide against the ethnic minority of the Tutsi people took place. Most of the victims belonged to the minority of the Tutsi (ca. 15\%) population group, ${ }^{1}$ It is also true that countless moderate Hutu refused to participate in the killings or tried to hide and protect Tutsi were murdered as well. Here, we need to keep in mind that the terms "Hutu," “Tutsi” and “Twa” (a minority of about 1\%) are not regular ethnic descriptions. Rather, they refer to groups of people sharing the same language and the same culture. These terms used to refer to one's profession. Herdsmen were Tutsi, while farmers were Hutu. The name Twa signifies the profession of the potter. ${ }^{2}$ It was only the colonial powers, first Germany, then - after World War I - Belgium, which cemented these divisions by way of their strategies of divide and rule. On account of this policy the religious sociologist Richard Friedli rightly speaks of an "historical responsibility of Europe"3 in view of Africa's ethno-political conflicts, including that of Rwanda.

After Rwanda’s independence in 1962, the rivalries between Hutu and Tutsi intensified. ${ }^{4}$ One example of the pervading injustice was the quota system that was implemented in 1975 in order to limit Tutsi employment in public service jobs and in educational institutions. ${ }^{5}$ Violence repeatedly escalated into massacres on both sides. Civil war started in 1990, culminating in the fastest genocide in recent human history. Next to its brevity, this genocide stood out due to its systematic preparation, its preventability and intensity, and its cruelty. ${ }^{6}$ Many victims - men, women, children - were cut into pieces and thrown into latrines to die. The excesses of sexual violence changed the world's legal treatment of rape and sexual violence and led to the inclusion of sexual crimes as genocidal crimes (“Akayesu Ruling” of 1998). Another disturbing

\footnotetext{
${ }^{1}$ Célestin Muyombano, Ruanda. Die historischen Ursachen des Bürgerkrieges (Stuttgart: Naglschmid, 1995), p. 30.

${ }^{2}$ Pascal Bataringaya, Versöhnung nach dem Genozid. Impulse der Friedensethik Dietrich Bonhoeffers für Kirche und Gesellschaft in Ruanda (Kamen: Spenner, 2012), p. 22.

${ }^{3}$ Richard Friedli, 'Der ethnopolitische Konflikt in Rwanda', in R. Moser, ed, Die Bedeutung des Ethnischen im Zeitalter der Globalisierung. Einbindungen. Ausgrenzungen. Säuberungen (Bern: Paul Haupt, 2000), pp. 133-149 at pp. 138-139. All translations CS, if not indicated otherwise.

${ }^{4}$ Bataringaya, Versöhnung nach dem Genozid, p. 24.

${ }^{5}$ Bataringaya, Versöhnung nach dem Genozid, p. 24. Cf. Muyombano, Ruanda, p. 44.

${ }^{6}$ Roméo Dallaire, commander of the UNAMIR-forces stationed in Rwanda during the genocide, recounts in this book his experiences during the genocide and points to the failure of the world community, which could have stopped the killings. Roméo Dallaire, Shake Hands with the Devil: The Failure of Humanity in Rwanda (London: Arrow, 2004).
} 
characteristic of this genocide is the historical reality that oftentimes victims and perpetrators knew each other. They were neighbours, friends or even family members.

At the time of the genocide, Rwanda was one of the most "Christian” countries in Africa, and possibly in the world. More than $90 \%$ of the population proclaimed adherence to the Christian faith, ${ }^{7}$ with almost two thirds of the population belonging to the Catholic tradition. This level of confession and adherence inevitably raises a question: What role did the churches play before and during the genocide? It was an ambiguous role, to say the least. While there are numerous examples of individual courage by pastors, priests and nuns who paid for their stance with their lives, ${ }^{8}$ others speak of a complicity of the churches in the genocide. Different from the massacres in previous years, when church buildings were respected as sanctuaries, this time they became death traps for the people seeking refuge. As political scientist Timothy Longman points out, "more people were killed in church buildings than anywhere else." ${ }^{9}$ Longman continues: "Numerous Tutsi priests, pastors, brothers, and nuns were killed, often by their own parishioners, sometimes by their fellow clergy... In some parishes, Hutu clergy attempted to protect those gathered within their church, but in many others, clergy assisted the killers.” ${ }^{10} \mathrm{At}$ the institutional level, most churches in Rwanda were mute. There was little leadership that would encourage people to speak out against the ideology and practice of hate. At the parish level, most pastors and priests were left to decide and act for themselves and, according to theologian Stephen D. Smith, "in many cases made surprisingly poor and disturbing choices." 11 At an individual level the unsettling question remains how the Gospel message of loving one's neighbour could be turned so easily into the action of killing one’s neighbour.

Despite this devastating picture, however, it was not the case that there were no voices at all opposing the violent hatred. One of these voices was Thaddée Nsengiyumva, Bishop of Kabgayi and President of the Rwandan Episcopal Conference. On December 1, 1991, he issued a pastoral letter "Convertissons-nous pour vivre ensemble dans la paix” ("Let us convert to live together in peace”). ${ }^{12}$ In this pastoral letter Nsengiyumva pointed self-critically to the church’s responsibility in perpetuating the ethnic division and called on the church to renew itself. After the genocide began, he made repeated appeals to stop the killing as he assisted the International

\footnotetext{
${ }^{7}$ Bataringaya, Versöhnung nach dem Genozid, p. 20.

${ }^{8}$ Cf. Carol Rittner, John K. Roth, and Wendy Whitworth, eds. Genocide in Rwanda. Complicity of the Churches? (St. Paul, Minnesota: Paragon House, 2004).

${ }^{9}$ Timothy Longman as quoted in Rittner, Roth, and Whitworth, Complicity of the Churches? pp. xi.

${ }^{10}$ Timothy Longman as quoted in Rittner, Roth, and Whitworth, Complicity of the Churches? pp. xii.

${ }^{11}$ Stephen D. Smith, 'Introduction', in C. Rittner, J.K. Roth, and W. Whitworth, eds, Genocide in Rwanda. Complicity of the Churches? (St. Paul, Minnesota: Paragon House, 2004), pp. 1-3 at p. 2.

12 Thaddée Nsengiyumva, Convertissons-nous pour vivre ensemble dans la paix (Diocése de Kabgayi/Gitarama, 1991).
} 
Committee of the Red Cross (ICRC) in helping the war-displaced people in his bishopric. ${ }^{13}$ For all his efforts Nsengiyumva was himself murdered on June 5, 1994. And still on January 1, 1994, weeks before the slaughter began, Christians from all religious confessions gathered for a peace march in Rwanda's capital Kigali, praying and appealing for peace. Once the killing had started in April, it was the Vatican (Pope John Paul II), on April 27 who was the first to publicly call the events in Rwanda a genocide and demand that the killings come to an end. ${ }^{14}$ There were certainly Christians in Rwanda, both known and unknown, who "stood firm against a tide of unprecedented atrocities, and who did not leave God without witnesses.”15 Nevertheless, the sombre impression remains: "the presence of Churches in a country guarantees exactly nothing.”16

\section{The Rwandan Churches and their Quest for Justice and Reconciliation}

Since the genocide, the religio-scape in Rwanda has been changing. ${ }^{17}$ The Catholic church lost about one third of its members as its membership decreased from about $65 \%$ pre-genocide to about 44\%. In marked contrast, the Protestant denominations have experienced a rise in membership. From 19\% in 1990, they have doubled to 38\% in $2015 .{ }^{18}$ Within the Protestant denominations, it is the Pentecostal branch that has gained particular momentum. The Church of the Seventh-Days Adventists is also showing a considerable growth rate, from $8 \%$ to $12 \%$. While there have been substantial shifts within the institutionalized Christian faith, the overall adherence to Christianity has remained stable with still more than $90 \%$ of the Rwandan population belonging to the Christian faith. It is due to this fact that the Christian churches are significant actors in today’s civil society. As Anne Kubai points out, "religion has been and continues to be part of Rwanda's system of meaning-making and meaning-interpretation, and hence has contributed to shaping new values, demands of propriety and interpretations of old

\footnotetext{
${ }^{13}$ At the same time, Thaddée Nsengiyumva's role seems somewhat ambiguous when on April 16 he issued a letter that could be understood in support of the Hutu government against the Tutsi rebellion. Cf. Laure Coret and François-Xavier Verschave, L'horreur qui nous prend au visage. L'Etat français et le génocide au Rwanda (Paris: Editions Karthala, 2005).

${ }^{14}$ UN Secretary-General Boutros-Ghali stated a week later that there is a genocide taking place in Rwanda.

15 John K. Roth, 'Epilogue. What should be remembered?', in C. Rittner, J.K. Roth, and W. Whitworth, eds, Genocide in Rwanda. Complicity of the Churches? (St. Paul, Minnesota: Paragon House, 2004), pp. 269-273 at p. 269.

${ }^{16}$ David Gushee, 'Why the churches were complicit. Confessions of a broken-hearted Christian', in C. Rittner, J.K. Roth, and W. Whitworth, eds, Genocide in Rwanda. Complicity of the Churches? (St. Paul, Minnesota: Paragon House, 2004), pp. 259-266 at p. 260.

${ }^{17}$ Online at <http://www. statistics.gov.rw > [accessed: 10 October 2017].

18 "National Institute of Statistics of Rwanda.” Online at <http://www.statistics.gov.rw/publication/rphc4thematic-report-socio-cultural-characteristics-population> [accessed: 10 October 2017].
} 
norms that have emerged after the genocide”. ${ }^{19}$ Contrary to many Western countries, the Christian churches in Rwanda assume a crucial role in all processes affecting Rwandan society, including the quest for democratization, justice and reconciliation.

I will now look in particular at the Église Presbytérienne au Rwanda, shortened to EPR. With about 300.000 members the Église is a rather small denomination, when compared with the Pentecostal Church (ADEPR) or the Rwandan Anglican Church each with about 2 million members. Its limited size and its ties to the German-based Faith-Based Organization (FBO) United Evangelical Mission (UEM) ${ }^{20}$ account for its accessibility as a case study, in the context of which I also conducted a modest empirical investigation by conducting several semistructured qualitative interviews. At the same time, the Église Presbytérienne’s engagement for reconciliation and peacebuilding is representative of the way that it is being echoed in other denominations as well.

The changes within Rwanda's religio-scape pre- and post-genocide reflect the challenges the churches faced after the genocide. These challenges were multi-facetted and included the emotional, pragmatic and organizational levels. Some denominations such as the Église Presbytérienne had lost more than half of its pastors and staff, not to mention significant numbers of its members. ${ }^{21}$ In addition to the challenges connected to their own losses, the churches had to find an answer to the question of how to grapple with their own moral and spiritual failure. Instead of being witnesses to truth and justice, confronting the seed of ethnic division and hatred with the Gospel's call to love and peace, (too) many participated in the horror by deeds of inaction or action. Nevertheless, looking back now, we need to keep in mind the remarks of Pulitzer Prize-winner Tina Rosenberg. We who "write and judge, we are cleareyed about the system's evil. ... We know how we would have behaved. It is [our] extreme good fortune that we will never face this test.”22

The Église Presbytérienne was the first - and still, as far as I know, the only - church which issued shortly after the genocide a Confession of Guilt, the Detmold Confession of $1996 .{ }^{23}$ In December 1996, a group of priests, pastors and lay people from different ethnic backgrounds, from Rwanda and different countries of refuge gathered at Detmold, Germany, to acknowledge

\footnotetext{
${ }^{19}$ Anne Kubai, ' 'Confession' and 'Forgiveness' as a Strategy for Development in Post-Genocide Rwanda', HTS Teologiese Studies/Theological Studies 42:4 (2016), 1-9 at 3.

${ }^{20}$ Online at http://www.vemission.org/en/about-uem/who-we-are.html [accessed: 10 October 2017].

${ }^{21}$ The Presbyterian Church lost 41 (i.e. more than half) of its pastors, elders and deacons and large numbers of its members in the genocide.

${ }^{22}$ Tina Rosenberg, The Haunted Land: Facing Europe's Ghost after Communism (New York: Random House, 1995), p.66.

23 “The Detmold Confession.” Online at <http://www.rwandahope.com/confession.pdf> [accessed: 10 October 2017].
} 
their wrongful action and lack of action and to ask for forgiveness. The first article of the Detmold Confession states: "The Rwandan people will never be reconciled with each other unless each party accepts to kneel down before the suffering of the other party, to confess their own offense and to humbly ask forgiveness of their victims." ${ }^{24}$ This article is followed by a confession of guilt from three perspectives, Hutu Christians, Tutsi Christians and western Christians. While the Hutu Christians repent their crimes such as "torturing, raping, slitting pregnant women open, hacking humans to pieces, burying people alive,”25 Tutsi Christians acknowledge positively the demand of forgiveness by the Hutu and they themselves ask for forgiveness for "blind vengeance which members of our group have taken." ${ }^{26}$ Western Christians repent their complicity in the suffering of the Rwandan people through the arms trade, neglect of refugees, silence and inaction. ${ }^{27}$ It is not least its encompassing character through its three-dimensional perspective that accounts for the wide reception of the Detmold Confession. Nevertheless, it was also met with contestation, in- and outside the church. ${ }^{28}$ Yet the unsparing openness, the self-critical authenticity of all partners involved, who accepted their guilt before God and before their Christian brothers and sisters and asked for forgiveness, formed a basis on which the Église Presbytérienne could build her engagement for reconciliation and justice. ${ }^{29}$

At this point, some terminological clarifications are called for. Reconciliation, originally at home in religious contexts, has become an established term in historical and political discourse. Societies-in-transition frequently draw on reconciliation to express their desire for a new beginning, for stability and progress, especially in the aftermath of political instability and violence. While I am aware of this term's multi-faceted meanings, I understand reconciliation here in terms similar to theologian Stephanie van de Loo: Reconciliation is a "reciprocal process between at least two parties, who in immediate or mediate contact with each other

\footnotetext{
${ }^{24}$ Article I of “The Detmold Confession.” Online at $<$ http://www.rwandahope.com/confession.pdf $>$ [accessed: 10 October 2017].

${ }^{25}$ Article II.1 of “The Detmold Confession.” Online at <http://www.rwandahope.com/confession.pdf $>$ [accessed: 10 October 2017].

${ }^{26}$ Article II.2 of "The Detmold Confession." Online at <http://www.rwandahope.com/confession.pdf $>$ [accessed: 10 October 2017].

${ }^{27}$ Article III.2 of “The Detmold Confession.” Online at <http://www.rwandahope.com/confession.pdf $>$ [accessed: 10 October 2017].

${ }^{28}$ One of the points of critique was that the Confession might be understood as incriminating whole groups of people in a sense of collective guilt. Cf. Célestin Nsengimana, Peacebuilding Initiatives of the Presbyterian Church in the Post-Genocide Rwandan Society. An Impact Assessment Geneva: Globethics.net (2015), p. 51. Online at <http://www.globethics.net/documents/4289936/13403252/GE_Focus_24_web.pdf> [accessed: 10 October 2017].

${ }^{29}$ For a more detailed discussion of the impact of the "Detmold Confession" on the Rwandan process of reconciliation, cf. Katharina Peetz, 'Das Schuldbekenntnis von Detmold und sein Stellenwert im ruandischen Versöhnungsprozess', in J. Enxing, ed, Schuld als Herausforderung für Theologie und Kirche (Ostfildern: Grünewald, 2015), pp. 249-261.
} 
reflect on their mutual relationship, and who aim to design this relationship in a positive and new way by mutual acceptance, as well as the result of this process." ${ }^{30}$ According to ethicist Fernando Enns, the process of reconciliation may include "different elements such as the confession of guilt, atonement, asking and granting of forgiveness ..., up to a newly ordered relationship". ${ }^{31}$

Reconciliation, however, cannot be separated from its underlying conception of justice. In this context, two concepts of justice come into view - those are retributive and restorative/transformative justice. While most of our western perception of justice is based on an understanding of justice as iustitia retributiva, sociologist Howard Zehr argues that this conception contains certain weaknesses. ${ }^{32}$ According to Zehr, it does not pay sufficient attention to the community and furthermore serves an abstraction of the victim, the perpetrator as well as the crime itself. Zehr, therefore, proposes supplementing the retributive conception of justice with a restorative or transformative understanding. ${ }^{33}$ Zehr bases his argument on a relational understanding of crime as a violation of people and relationships. Justice thus requires the victim, the offender and the community to engage in a joint search for solutions that aim at reconciliation and the healing of relationships. ${ }^{34}$ While punishment of the perpetrator, especially in the form of reparations, may be part of the process, it is not its primary goal. It is especially the focus on relationships that accounts for the productivity of the transformative approach in the context of Rwanda.

Rwanda's current government with President Paul Kagame is aware that the road to national unity, development and economic growth leads through reconciliation. With his ambitious goal to make Rwanda into Africa’s Singapore, ${ }^{35}$ he has turned reconciliation into a political tool. His National Politics of Reconciliation thus pushes reconciliation on several levels. At the national

\footnotetext{
${ }^{30}$ Stephanie van de Loo, Versöhnungsarbeit. Kriterien - theologischer Rahmen - Praxisperspektiven (Stuttgart: Kohlhammer, 2009), p.16. My emphasis.

31 Fernando Enns, 'Transformative Gerechtigkeit als Möglichkeitsraum zur Versöhnung', Kirchliche Zeitgeschichte 26 (2013), 23-35 at 24.

${ }^{32}$ Howard Zehr, Changing Lenses. A New Focus for Crime and Justice (Scottdale: Herald Press, 2005).

${ }^{33}$ I prefer the term "transformative" justice over the term "restorative" justice, since restorative carries the connotation as if the aim is the restoration of the status quo ante. In the case of Rwanda, however, the status quo ante was characterized by injustice as well. Transformative justice, on the other hand, implies a genuine change towards the better, a change of injustice towards justice.

${ }^{34}$ Zehr, Changing Lenses, p. 37. For a theological perspective cf. Miroslav Volf, Exclusion and Embrace. A Theological Exploration of Identity, Otherness, and Reconciliation (Nashville: Abingdon, 1996). Based on his own experience of the Balkan War in his native Croatia, Volf emphasizes the relational dimension of conflict by his two key concepts - exclusion and embrace. According to Volf, exclusion constitutes the root of conflict and sin, while embrace functions as the metaphorical model of reconciliation. "At the core of the Christian faith lies the persuasion that the 'others' need not be perceived as innocent in order to be loved, but ought to be embraced even when they are perceived as wrongdoers.” Volf, Exclusion and Embrace, p. 85. See also Nicholas Wolterstorff, Journey toward Justice: Personal Encounters in the Global South (Grand Rapids: Baker, 2013).

${ }^{35}$ Daniel Ammann, ‘A Country of Hope', Credit Suisse Bulletin: Africa, Rise of a Continent 3 (2015), 30-45. Online at <http://publications.credit-suisse.com/> [accessed 10 October 2017].
} 
level, the National Unity and Reconciliation Commission (NURC) was founded that offers nationwide diverse reconciliation projects, such as the so-called "reconciliation villages", where victims and perpetrators live side by side. At the judicial level, Rwanda has turned to its traditional courts of justice, the gacaca. ${ }^{36}$ The terms “Hutu”, “Tutsi” and "Twa” were forbidden. Instead, Rwandan unity is now being proclaimed under the official motto "We are all Rwandan.”

The churches, as significant players in civil society, partner with the government in their common concern for reconciliation. In an interview, the current President of the Église Presbytérienne , Pascal Bataringaya, has outlined his priorities for his term of office: "First, evangelization and church growth, second, reconciliation. But both go together." ${ }^{37}$ Churches like the Église Presbytérienne offer a variety of activities aimed at reconciliation. At an institutional level, the church's Center for Formation and Documentation aims "to serve as a cornerstone to the unity and reconciliation process for the people of Rwanda" 38 through the training of pastors and church staff in issues of conflict resolution, reconciliation and justice. Since 2016, this Center is supported by the newly founded Dietrich Bonhoeffer Research Center for Public Theology. At the parish level, different reconciliation projects take place, such as that is which is happening in the parish of Remera. Here the pastor and trained mediator Jerome Bizimana leads a peacemaking group called the Lights. Its aim is the buildingof relationships between perpetrators and survivors, thus encouraging a healing processes. The coordination of these reconciliation endeavours with developmental projects (such as micro-loans for establishing a joint business) enhances the sustainability of both reconciliation and developmental projects. Similar projects are found in other church denominations throughout the country..

\section{Whose Justice? Which Democracy? Challenges For Public Theology}

\footnotetext{
${ }^{36}$ Gacaca [ga'tfatfa] means "grass" and refers to the place in the villages where judicial hearings are held. For a detailed discussion of the gacaca courts, see Sebastian Friese, Politik der gesellschaftlichen Versöhnung: Eine theologisch-ethische Untersuchung am Beispiel der Gacaca-Gerichte in Ruanda. Theologie und Frieden no. 39 (Stuttgart: Kohlhammer, 2010), pp. 53-86.

${ }^{37}$ Interview conducted by the author with Pascal Bataringaya, President of the Presbyterian Church of Rwanda. Kigali, February 21, 2016.

38 This centre, according to its self-description, is meant "on one hand, to contribute to the reconstruction of the vitality of religious denominations after the 1994 Genocide tragedy, and, on the other hand, to serve as a cornerstone to the unity and reconciliation process for the people of Rwanda." "EPR. Historical Background." Online at <http://cfd.epr.rw/index.php/en/cfdhome/historical-background> [accessed 10 October 2017].
} 
The final part of this article sets the reconciliation activities of the Rwandan churches into a wider context by asking how they relate to an overall concern for justice and democracy. Alasdair MacIntyre reminds us that when we speak of justice, we need to specify whose justice we refer to and what exactly we mean by this term. ${ }^{39}$ The same holds true for the term democracy. This matters of perspective can be set within and alongside the purpose and practice of a public theology.

The German public theologian Heinrich Bedford-Strohm observes that public theology is characterized by its engagement with questions of public relevance, by its glocal-ness and its inclusion of concrete political challenges into its theological reflection. ${ }^{40}$ One prominent example of the theological reflection of public issues was the German pastor Dietrich Bonhoeffer, who was killed by the Nazis for his participation in a planned coup d'état that included the assassination of Hitler. In his famous speech to German pastors in 1933, "The Church and the Jewish Question,” Bonhoeffer described the responsibility of the churches towards the state in three ways. The first of these captures exactly one of the central tasks of public theology, ${ }^{41}$ namely "questioning the state as to the legitimate character of its actions, that is, making the state responsible for what it does." 42

If one feature of a public theology is concerned with asking the state about the legitimacy, - that is, the justness, of its action - then what might be the specific challenges to the Rwandan churches in this regard? Here I speak as an outsider. I do not call Rwanda home, nor do I speak the language and my knowledge of its cultures is imperfect. This calls for humility and the awareness that one's own perspective is very limited. The outsider's perspective comes with a number of limitations but it is not without some advantages. As an outsider, perhaps one can bring a different, a fresh perspective and be somewhat less inhibited. come from a perspective of tremendous admiration and respect for the extraordinary work that the Rwandan churches are doing in their specific post-genocide context.

Now let us come back to our starting question: How can a public theology advance the task of democracy in order to bring forth justice for all? In view of the churches’ role in post-genocide

\footnotetext{
${ }^{39}$ MacIntyre points to the "conflicting conceptions of justice, conceptions which are strikingly at odds with one another in a number of ways." What makes consensus especially difficult is the fact that, according to MacIntyre, there are "fundamental disagreements about the character of rationality." Alasdair MacIntyre, Whose Justice? Which Rationality? (Notre Dame: University of Notre Dame Press, 1988), pp. 1, 4.

${ }^{40}$ Bedford-Strohm points to five characteristics of public theology: Next to the three already mentioned, he names interdisciplinarity and bilinguality. Heinrich Bedford-Strohm, 'Politik und Religion - Öffentliche Theologie', Verkündigung und Forschung 54:2 (2009), 42-55 at 53.

${ }^{41}$ Cf. Heinrich Bedford-Strohm, 'Dietrich Bonhoeffer als öffentlicher Theologe', Evangelische Theologie 69:5 (2009), 329-341 at 335.

42 Dietrich Bonhoeffer, 'The Church and the Jewish Question', in D. Bonhoeffer, Berlin: 1932-1933, DBWE 12, edited by L. Rasmussen (Minneapolis: Fortress Press, 2009), pp. 361-371 at p. 365.
} 
Rwanda, there are two areas in particular to focus upon. The first concerns the relationship between justice and reconciliation; the second has to do with the relationship between justice, ethnic pluralism and democracy.

(1.) Reconciliation needs justice. Without justice reconciliation falls prey to the danger of turning into a sham. In this regard, John Paul Lederach's four-dimensional concept of reconciliation is helpful. Lederach understands reconciliation as the combination of peace, justice, mercy and truth. ${ }^{43}$ All four aspects must find adequate consideration in reconciliation processes. Yet in the context of the Rwanda churches, the churches' emphasis on peace and mercy seems at times to go to the detriment of justice and truth. ${ }^{44}$ After the genocide in May 1998, Rakiya Omaar, Director of the London-based group African Rights, published "An Open Letter to His Holiness, Pope John Paul II,” criticizing him and the Vatican for exploiting the concept of reconciliation while neglecting the need for justice. She claimed that, "We need more truth and justice.” ${ }^{45}$ Omaar's concern regarding an exploitation of the concept of reconciliation is taken further by Stef Jansen's observations in the context of the Balkans after the Balkan wars. He cautioned that when speaking of reconciliation, we need to consider carefully whose reconciliation is desired and by whom, for whom, and for what purpose. By his inquiry into "if reconciliation is the answer, are we asking the right questions?”, Jansen drew attention to important alternative questions that might remain unasked, particularly in the context of justice. ${ }^{46}$ By way of example, he pointed to the significance of "mutual recognition" in reconciliation processes, for instance, as victims from opposing sides recognize each other as mothers who are grieving the loss of husbands or sons. From the perspective of reconciliation, one needs to ask which socially-sanctioned positions in terms of gender, class, urban/rural division, for instance are helpful for people to engage in mutual recognition processes with former enemies and which social positions are detrimental to these efforts. If relationships are entirely asymmetrical, reconciliation may, according to Jansen, actually serve to "reinforce existing social patterns of inequality." ${ }^{47}$ Paying attention to all four components

\footnotetext{
43 John P. Lederach, 'Justpeace', in European Centre for Conflict Prevention, People Building Peace (Utrecht: European Centre for Conflict Prevention, 1999), pp. 27-36.

${ }^{44}$ In a similar vein, Josephine Sundqvist remarks in her study of the Pentecostal Movement and its implications on the reconciliation process "that the Pentecostal movement has barely been emphasizing justice in their reconciliation strategy or their interpretation of the concept.” Josephine Sundqvist, 'Reconciliation as a Societal Process. A Case Study on the Role of the Pentecostal Movement (ADEPR) as an Actor in the Reconciliation Process in Post-Genocide Rwanda', Swedish Missiological Themes 99:2 (2011), 157-195 at 169.

45 Rakiya Omaar, 'Open Letter to His Holiness, Pope John Paul', Online at <https://www.pambazuka.org/humansecurity/letter-pope-african-rights> [accessed: 10 October 2017].

${ }^{46}$ Stef Jansen, 'If reconciliation is the answer, are we asking the right questions?' Studies in Social Justice 7:2 (2013), 229-243.

47 Jansen, If reconciliation is the answer, p. 236.
} 
of reconciliation - peace, justice, mercy and truth - can thus help to counter such a one-sided perception of reconciliation. ${ }^{48}$

(2.) Justice, ethnic pluralism and democracy. It remains an open question whether there are long-term benefits to Rwanda's official policy of denying an open ethnicity discourse. Ethnicity has been turned into a social taboo. The creation of a new social identity ("We are all Rwandan”) by decree, however, neglects the difference between making an illegitimate qualitative or even moral distinction between different ethnic groups of people and a legitimate descriptive, formal distinction. The policy not only allows the latter for the acknowledgement or even celebration of differences, but its denial comes with a series of severe problems. One current example of the difficulties that arise from this policy of ethnic taboo is the situation of the Twa. The people of the Twa or Batwa are counted among the so-called pygmies and constitute a small minority of about 1\% in Rwanda. Mostly hunters and gatherers, the Twa used to live predominately in the woods. Recent years, however, have seen the expulsion of the Twa from their habitat in forests for the sake of creation of natural parks. ${ }^{49}$ Being deprived of their livelihoods and combined with persistent negative stereotypes against them, the Twa face severe poverty and discrimination in terms of education, housing and employment. In April 2016, the "UN Committee on the Elimination of Racial Discrimination” warned that the people of the Twa are threatened by extinction. ${ }^{50}$ Per official laws, however, no ethnicity exists in Rwanda: there is then no problem that is specifically related to the Twa. Rwanda's refusal to acknowledge the people of the Twa - instead, the government speaks exclusively of "marginalized groups"51 - threatens their very existence. Instead of creating unity and social cohesion, the denial of ethnic pluralism comes here with the danger of furthering a different kind of injustice.

\footnotetext{
${ }^{48}$ Despite the differences in context, helpful parallels might be drawn to South Africa, where Christo Thesnaar calls attention to the different dimensions of reconciliation. "The main challenge is to ensure that all generations are involved in this process, that subsequent generations are heard, and that their needs are recognized socioeconomic justice, restitution, and transformation - forming part of the broader process of reconciliation.” Christo Thesnaar, 'Alternative and Innovative Approaches to Reconciliation: A South African Perspective', in M. Leiner and C. Schliesser, eds. Alternative Approaches in Conflict Resolution (London/New York: Palgrave Macmillan, 2018), pp. 125-136 at p. 134.Thesnaar thus calls on the "faith communities to put forth active public theologians, with a clear mandate to contribute to the process of healing and reconciliation." Thesnaar, A South African Perspective, 134.

49 “Committee on the Elimination of Racial Discrimination examines report of Rwanda, April 29, 2016.” Online at <http://www.ohchr.org/EN/NewsEvents/Pages/DisplayNews.aspx?NewsID=19908\&LangID=E $>$ [accessed: 10 October 2017].

50 "Committee on the Elimination of Racial Discrimination examines report of Rwanda, April 29, 2016.” Online at <http://www.ohchr.org/EN/NewsEvents/Pages/DisplayNews.aspx?NewsID=19908\&LangID=E > [accessed: 10 October 2017].

51 “Committee on the Elimination of Racial Discrimination examines report of Rwanda, April 29, 2016." Online at <http://www.ohchr.org/EN/NewsEvents/Pages/DisplayNews.aspx?NewsID=19908\&LangID=E> [accessed: 10 October 2017].
} 
The Rwandan government has achieved much, no doubt. Yet it remains the on-going task of the churches, not only in Rwanda, to question, with Bonhoeffer, "the state as to the legitimate character of its actions, that is, making the state responsible for what it does." ${ }^{52}$ This task is at the very core of a theology that understands itself as public theology. When the state speaks of justice and democracy, the churches in Rwanda and beyond need to ask critically: Whose justice is being advocated - and whose justice is being neglected? What kind of democracy is being pursued - and what are its blind spots?

\footnotetext{
${ }^{52}$ Bonhoeffer, The Church and the Jewish Question, p. 365.
} 